УДК $547.99+630 * 813.1+631.8$

\title{
ВЛИЯНИЕ СТИМУЛЯТОРА РОСТА РАСТИТЕЛЬНОГО ПРОИСХОЖДЕНИЯ НА МОРФОГЕНЕЗ IRIS SIBIRICA L., HEDYSARUM TEINUM KRASNOB. И SYRINGA VULGARIS L. В КУЛЬTУPE IN VITRO
}

\author{
() Н.Г. Базарнова, Л.И. Тихомирова", Н.С. Фролова, А.Е. Павлуиин, Е.А. Курчанова \\ Алтайский государственный университет, пр. Ленина, 61, Барнаул, 656049 \\ (Россия), e-mail: L-tichomirova@yandex.ru
}

Изучена ростостимулирующая активность продуктов карбоксиметилирования растительного сырья при использовании их в питательные среды для микроклонального размножения растений Iris sibirica, Syringa vulgaris, Hedysarum teinum. Стимулирующее действие на геммо- и ризогенез у ириса сибирского и копеечника чайного обусловлено более высоким содержанием карбоксиметилированного лигнина в составе карбоксиметилированного растительного сырья. На основании полученных данных физиологическое действие данного стимулятора можно отнести к ауксиновому типу. Отмечен положительный эффект от введения карбоксиметилированного растительного сырья в питательные среды у ряда растений в коллекции in vitro.

Ключевые слова: стимулятор роста, морфогенез, in vitro, геммогенез, ризогенез, ауксины, Iris sibirica, Syringa vulgaris, Hedysarum teinum.

\section{Введение}

Фитогормоны - органические сравнительно низкомолекулярные соединения, которые в малых количествах необходимы для запуска и реализации физиологических программ, с помощью которых осуществляется взаимодействие клеток, тканей и органов [1,2].

Выделяют пять групп классических фитогормонов: цитокинины (зеатин, кинетин и 6-бензиламинопурин), гибберилины (гиббереллин А3), абсцизины (абсцизовая кислота (АБК)), ауксины (входят 3-индолилуксусная кислота (ИУК), $\alpha$-нафтилуксусная кислота (НУК), дихлорфеноксиуксусная кислота $(2,4-$ - )) и др. [1-7].

Ауксины являются обязательными участниками координации процессов морфогенеза, оказывающими влияние на деление, рост, инициирующими репликации ДНК. Под влиянием ауксинов продолжительность различных периодов митотического цикла уменьшается, что приводит к значительному ускорению темпов размножения клеток [1, 4-7].

Большое количество ауксинов в тканях - это сигнал о росте побегов: растению требуется больше

Базарнова Наталья Григорьевна - заведующая кафедрой органической химии, профессор, доктор химических наук, тел.: (3852) 36-95-37, e-mail: bazarnova@chem.asu.ru

Тихомирова Людмила Ивановна - заведующая отделом биотехнологий, кандидат биологических наук, e-mail: L-tichomirova@yandex.ru

Фролова Наталья Сергеевна - магистрант, e-mail: dinamogirl@mail.ru

Павлушин Александр Евегеньевич - магистрант, e-mail: sinscorpion90@mail.ru

Курчанова Евгения Андреевна - магистрант, e-mail: kurchanovaea@gmail.com воды и минеральных веществ, т. е. оно должно образовывать большее число корней. Ауксины стимулируют ризогенез - закладку придаточных корней на стебле и боковых корней на главном корне. Ауксины считаются одними из основных гормонов растений. Это привлекает многих ученых к исследованию их роли и механизма действия $[7,8]$.

Ранее было установлено, что продукты карбоксиметилирования различного растительного сырья содержат в своем составе карбоксиметилированные лигнин, целлюлозу, гемицеллюлозы, что под-

\footnotetext{
* Автор, с которым следует вести переписку.
} 
тверждено квантово-химическими расчетами, а некоторые фрагменты карбоксиметилированного лигнина, входящего в состав карбоксиметилированного растительного сырья, обладают ростостимулирующей активностью ауксинового типа [12].

Цель работы - изучить влияние стимулятора роста растительного происхождения карбоксиметилированной древесины на морфогенез Iris sibirica L., Hedysarum teinum Krasnob. и Syringa vulgaris L. в культуре in vitro.

\section{Экспериментальная часть}

Объекты исследований - растения-регенеранты ириса сибирского, сорт Лаула, сирени, сорт Огни Донбасса, и Hedysarum teinum Krasnob (копеечник чайный).

Экспериментальные работы с использованием метода культуры тканей проведены по общепринятым методикам [13]. Растительные ткани культивировали на питательных средах MS [14].

Для постановки опыта готовили среды на минеральной основе $1 \frac{1}{2} \mathrm{MS}$. Использовали синтетические фитогормоны ауксинового типа действия: ИУК (3-индолилуксусную кислоту), НУК ( $\alpha$-нафтилуксусную кислоту), ИМК (3-индолилмасляную кислоту) в количестве 3 мкМ, или примерно 0,6 мг/л.

Негормональный стимулятор роста брали в концентрации 25, 50 75, 100 мг/л. В качестве контроля побеги высаживали на безгормональные среды на основе $1 / 2 \mathrm{MS}$.

Карбоксиметилированное растительное сырье получено воздушно-сухой соломы пшеницы, древесины сосны и костры льна с фракцией 0,63-0,315 мм, влажностью 4-7\%, с содержанием целлюлозы 37$46 \%$ и содержанием лигнина $19-36 \%$.

Карбоксиметилирование проводилось по стандартной методике [10]. Исследование продуктов на содержание карбоксиметильных групп, вводимых при реакции, изучали методом кондуктометрического титрования [11]. Растворимость полученных образцов определяли в соответствии с методикой, основанной на растворении продукта в воде и последующей фильтрации этого раствора через пористый фильтр. Свойства продуктов представлены в таблице 1 .

В каждом варианте опыта выращивали по 20 растений, число повторностей было равно 3. Изучали влияние карбоксиметилированного растительного сырья на число побегов, их высоту, число корней и длину корней на этапе укоренения. Перемножая число побегов на их длину, получали общую длину побегов. Число корней, умноженное на длину, давало общую длину корней.

Растения содержали в лаборатории при искусственном освещении (2000-4000 лк) в условиях фотопериода: $16 / 8$ ч свет/темнота и температуре $24-26^{\circ} \mathrm{C}$.

Статистический анализ проводили в MS Excel 2007 с использованием стандартных показателей [15, 16].

Таблица 1. Свойства карбоксиметилированного растительного сырья

\begin{tabular}{l|c|c|c|c}
\hline \multicolumn{1}{c|}{ Исходное сырье } & Содержание КМГ, \% & $\begin{array}{c}\text { Растворимость } \\
\text { в воде, } \%\end{array}$ & $\begin{array}{c}\text { Относительная } \\
\text { вязкость КМД }\end{array}$ & Содержание КМЦ, \% \\
\hline Солома пшеницы & $22,7 \pm 0,6$ & $82 \pm 1$ & $1,09 \pm 0,01$ & $32,6 \pm 0,6$ \\
Костра льна & $17,3 \pm 0,6$ & $74 \pm 1$ & $1,10 \pm 0,01$ & $55,0 \pm 0,6$ \\
Древесина сосны & $15,7 \pm 0,6$ & $68 \pm 1$ & $1,07 \pm 0,01$ & $35,3 \pm 0,6$ \\
\hline
\end{tabular}

\section{Обсуждение результатов}

Этап укоренения на питательных средах микроклонально размноженных растений является, несомненно, важным этапом в получении качественного посадочного материала. Предварительно укорененные побеги лучше переносят процесс начальной адаптации. На этапе укоренения часто применяют среду Мурасиге и Скуга. Но при этом обычно изменяют основной состав за счет уменьшения в 2 раза количества минеральных солей. Корнеобразование стимулируют добавлением в среду ауксинов, полностью исключая цитокинины. При низких концентрациях ауксины инициируют ризогенез, а при высоких преобладает образование каллуса. При отсутствии или экономии ауксинов укоренение можно проводить и на безгормональной среде.

Ирис сибирский относится к легкоукореняемой культуре. При введении карбоксиметилированного сырья на основе древесины сосны в среды величина количественных показателей этапа укоренения зависела от концентрации стимулятора. На низких концентрациях (25, 50 мг/л) данные показатели незначительно превышали контроль. Увеличение содержания негормонального стимулятора (75, 100 мг/л) приводило к 
увеличению числа побегов на $10 \%$, высоты побегов - на $30 \%$, числа корней - на $31 \%$ и длины корней - на $35 \%$ по сравнению с контролем. Формирующаяся на безгормональной среде корневая система регенерантов характеризовалась слабым развитием и отсутствием корней второго порядка. По этой причине регенеранты имели небольшую площадь питания и слабую поглотительную способность, что в свою очередь отрицательно сказалось на этапе их адаптации к нестерильным условиям (табл. 2).

При сравнении влияния КМД на органогенез ириса с действием синтетических фитогормонов отмечали незначительное увеличение показателей под действием негормонального стимулятора роста. Действие КМД на регенеранты ириса сибирского можно отнести к ауксиновому типу. КМД стимулировал ризогенез - закладку придаточных корней на побеге и боковых корней на главном корне (рис.). Растениярегенеранты развивали мощную корневую систему, легко проходили этап адаптации к нестерильным условиям. Число побегов было практически равно контролю, что говорит о влиянии остаточного количества цитокинина в тканях регенеранта, введенного в среды размножения [17].

Таблица 2. Влияние гормональных и негормонального стимуляторов роста на основе древесины сосны на показатели этапа укоренения ириса сибирского сорт Лаула

\begin{tabular}{l|c|c|c|c|c|c}
\hline \multirow{2}{\text{Гормональный}}{$\begin{array}{c}\text { Гемтав пита- } \\
\text { сеслогенез }\end{array}$} & $\begin{array}{c}\text { число } \\
\text { тельнй среды }\end{array}$ & $\begin{array}{c}\text { высота } \\
\text { побегов, шт }\end{array}$ & $\begin{array}{c}\text { общая высота } \\
\text { побегов, мм }\end{array}$ & $\begin{array}{c}\text { число } \\
\text { корней, шт. }\end{array}$ & $\begin{array}{c}\text { длина корней, } \\
\text { мм }\end{array}$ & $\begin{array}{c}\text { общая длина } \\
\text { корней, мм }\end{array}$ \\
\hline Контроль, & $6,8 \pm 0,5$ & $57,8 \pm 2,6$ & 393,0 & $4,8 \pm 0,4$ & $24,2 \pm 2,2$ & 116,2 \\
без гормонов & & & & & & \\
25 мг/л КМД & $7,0 \pm 0,5$ & $64,6 \pm 2,8$ & 452,2 & $4,8 \pm 0,3$ & $26,0 \pm 2,0$ & 124,8 \\
50 мг/л КМД & $7,0 \pm 0,5$ & $72,5 \pm 2,9$ & 507,5 & $4,9 \pm 0,3$ & $25,9 \pm 2,3$ & 126,9 \\
75 мг/л КМД & $7,4 \pm 0,5$ & $73,6 \pm 3,0$ & $\mathbf{5 4 4 , 6}$ & $5,9 \pm 0,3$ & $32,6 \pm 2,0$ & $\mathbf{1 9 2 , 3}$ \\
100 мг/л КМД & $7,5 \pm 0,5$ & $76,0 \pm 2,6$ & $\mathbf{5 7 0 , 0}$ & $6,3 \pm 0,4$ & $32,8 \pm 2,1$ & $\mathbf{2 0 6 , 6}$ \\
3 мкМ НУК & $7,9 \pm 0,8$ & $71,6 \pm 2,3$ & $\mathbf{5 6 5 , 6}$ & $6,1 \pm 0,4$ & $25,6 \pm 1,4$ & $\mathbf{1 5 6 , 2}$ \\
3 мкМ ИМК & $7,1 \pm 0,7$ & $76,5 \pm 3,1$ & $\mathbf{5 4 3 , 2}$ & $6,2 \pm 0,6$ & $29,8 \pm 2,0$ & $\mathbf{1 8 4 , 8}$ \\
\hline Среднее & & & 530,5 & & & 158,3 \\
\hline
\end{tabular}

Примечание. Полужирным шрифтом указаны показатели выше средних значений.

Влияние КМД на общую высоту побегов и общую длину корней у ириса сибирского в сравнении с действием синтетических фитогормонов ИМК и НУК

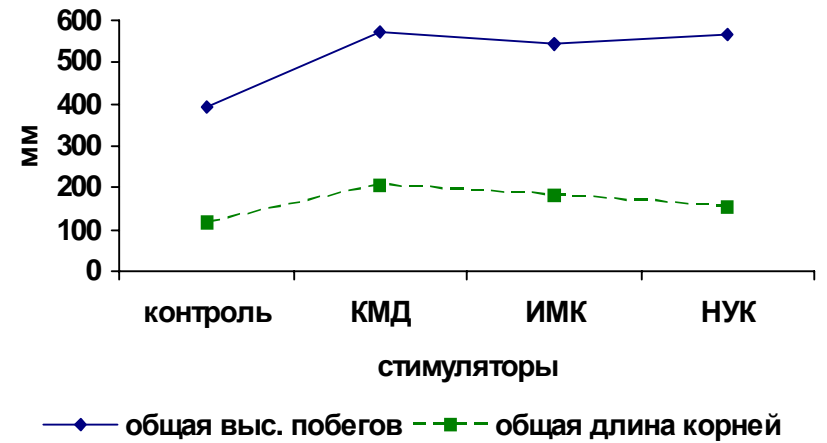

Копеечник чайный (Hedysarum teinum) является трудноразмножаемым объектом в культуре in vitro. Для данного вида характерно низкое значение числа укорененных побегов. По результатам опыта можно сказать, что геммогенез и ризогенез у копеечника на средах, содержащих карбоксиметилированное сырье на основе соломы пшеницы, проходили на том же уровне, что и на средах с синтетическими гормонами. Но, учитывая высокую стоимость синтетических фитогормонов, использование КМД экономически более выгодно.

Процент укоренившихся растений в пределах опыта был 23,0-49,9. Содержание в питательной среде 75 мг/л было выбрано в результате опыта, так как данный препарат ранее не был испытан на культурах при микроразмножении вообще, на копеечнике в частности. Следует отметить положительное влияние КМД на длину корней, что не характерно для синтетических фитогормонов. Общая длина корней под действием КМД увеличилась в 5,3 раза по сравнению с контролем и в 2,5 по сравнению с действием синтетических ауксинов (табл. 3). 
Таблица 3. Влияние гормональных и негормонального стимуляторов роста на основе соломы пшеницы на морфогенез Hedysarum teinum на этапе укоренения

\begin{tabular}{l|c|c|c|c|c|c}
\hline \multicolumn{1}{c|}{$\begin{array}{c}\text { Гормональный } \\
\text { состав питательной } \\
\text { среды, мкМ }\end{array}$} & $\begin{array}{c}\text { число } \\
\text { побегов, шт. }\end{array}$ & $\begin{array}{c}\text { высота } \\
\text { побегов, мм }\end{array}$ & $\begin{array}{c}\text { число } \\
\text { побегов, шт }\end{array}$ & $\begin{array}{c}\text { высота } \\
\text { побегов, мм }\end{array}$ & $\begin{array}{c}\text { число } \\
\text { побегов, шт. }\end{array}$ & $\begin{array}{c}\text { высота } \\
\text { побегов, мм }\end{array}$ \\
\hline $\begin{array}{l}\text { Контроль } \\
\text { без гормонов }\end{array}$ & $1,15 \pm 0,04$ & $40,7 \pm 2,2$ & 46,8 & $1,6 \pm 0,3$ & $14,3 \pm 1,0$ & 22,9 \\
3 мкМ ИУК & $1,2 \pm 0,02$ & $48,7 \pm 6,2$ & 58,6 & $3,4 \pm 0,4$ & $11,6 \pm 0,8$ & 39,4 \\
3 мкМ НУК & $1,25 \pm 0,06$ & $40,7 \pm 2,7$ & 50,9 & $4,0 \pm 0,4$ & $12,9 \pm 0,9$ & 51,0 \\
3 мкМ ИМК & $1,4 \pm 0,1$ & $35,2 \pm 2,0$ & 49,3 & $3,2 \pm 0,4$ & $14,4 \pm 0,8$ & 46,08 \\
& & & & & $40,3 \%$ & \\
КМД 75 мг/л & 1,0 & $45,8 \pm 3,1$ & 45,8 & $3,7 \pm 0,1$ & $33,1 \pm 5,4$ & $\mathbf{1 2 2 , 4}$ \\
\end{tabular}

Примечание. Полужирным шрифтом указаны показатели выше средних значений.

Сирень. Изучая действие стимуляторов роста на геммогенез и ризогенез сирени, отмечали усиление корнеобразования под действием синтетических ауксинов НУК и ИМК. Число корней на средах с ауксинами превышало контроль на 1,5-1,7 раз, при этом длина корней была ниже, чем в контроле. При использовании растительных стимуляторов роста на основе костры льна в количестве 25-100 мг/л не отмечали усиления регенерационных процессов по сравнению с контролем. Было отмечено на средах с КМД (75 и 100 мг/л) явление угнетения: низкий тургор ткани, некроз листьев, число побегов равно 1,0, число корней в 2 раза ниже, чем в контроле. На средах с концентрацией 25-50 мг/л показатели гемо- и ризогенеза были на уровне контроля. Ранее было показано, что повышенное содержание карбоксиметилцеллюлозы в костре льна не оказывает влияния на геммогенез и ризогенез.

Технологии клонального микроразмножения представляют исключительную ценность для поддержания и сохранения коллекций, и особенно в тех случаях, когда вид или сорт представлен ограниченным количеством экземпляров. На безгормональных средах растения гибнут. Для сохранения культур в коллекции используют питательные среды с низким содержанием синтетических фитогормонов. Нами выявлено, что побеги Iris sibirica, Potentilla alba, Hedysarum teinum, Potentilla fragarioides на среде с использованием карбоксиметилированного растительного сырья в концентрации 50 мг/л в течение шести месяцев находятся в стадии умеренного роста.

Таблица 4. Влияние гормональных и негормонального на основе костры льна стимуляторов роста на морфогенез сирени сорта Огни Донбасса на этапе укоренения

\begin{tabular}{|c|c|c|c|c|c|c|}
\hline \multirow{2}{*}{$\begin{array}{c}\text { Гормональный состав } \\
\text { питательной среды }\end{array}$} & \multicolumn{3}{|c|}{ Геммогенез } & \multicolumn{3}{|c|}{ Ризогенез } \\
\hline & $\begin{array}{c}\text { число } \\
\text { побегов, шт. }\end{array}$ & $\begin{array}{c}\text { высота } \\
\text { побегов, мм }\end{array}$ & $\begin{array}{c}\text { число } \\
\text { побегов, шт }\end{array}$ & $\begin{array}{c}\text { высота } \\
\text { побегов, мм }\end{array}$ & $\begin{array}{c}\text { число } \\
\text { побегов, шт. }\end{array}$ & $\begin{array}{c}\text { высота } \\
\text { побегов, мм }\end{array}$ \\
\hline $\begin{array}{l}\text { Контроль, без гормо- } \\
\text { нов }\end{array}$ & $1,2 \pm 0,4$ & $35,4 \pm 4,2$ & 40,71 & $3,7 \pm 0,5$ & $36,7 \pm 4,5$ & 135,8 \\
\hline 25 мг/л КМД & $1,3 \pm 0,2$ & $30,0 \pm 2,2$ & 37,5 & $4,0 \pm 0,6$ & $25,9 \pm 2,2$ & 103,6 \\
\hline 50 мг/л КМД & $1,3 \pm 0,5$ & $30,0 \pm 1,7$ & 39,9 & $3,3 \pm 0,5$ & $30,8 \pm 1,7$ & 102,6 \\
\hline 75 мг/л КМД & 1,0 & $37,5 \pm 6,5$ & 37,5 & $2,0 \pm 0,5$ & $18,6 \pm 9,5$ & 37,2 \\
\hline 100 мг/л КМД & $1,2 \pm 0,1$ & $24,9 \pm 3,3$ & 28,9 & $3,2 \pm 0,5$ & $24,6 \pm 4,5$ & 77,7 \\
\hline ЗмкМ НУК & $1,1 \pm 2,6$ & $35,6 \pm 4,4$ & 40,6 & $6,3 \pm 2,4$ & $16,6 \pm 6,3$ & 104,3 \\
\hline 3 мкМ ИМК & $1,8 \pm 0,1$ & $28,7 \pm 9,2$ & 33,9 & $5,3 \pm 0,65$ & $18,3 \pm 3,2$ & 93,7 \\
\hline
\end{tabular}

\section{Bыводы}

Введение стимулятора роста растительного происхождения в питательные среды на этапе укоренения оказывало стимулирующее действие на геммо- и ризогенез у ириса сибирского и копеечника чайного. На основании полученных данных физиологическое действие данного стимулятора можно отнести к ауксиновому типу. В отличие от синтетических гормонов КМД не только увеличивал число корней, но и усиливал рост побегов и корней в длину. Опыты по изучению влияния на морфогенез сирени необходимо продолжить, так как использованный стимулятор на основе костры льна содержал повышенное содержание карбоксиметилцеллюлозы, которая не оказывает ростостимулирующего действия. Отмечен положительный эффект от введения КМД в питательные среды у ряда растений в коллекции in vitro. 


\section{Список литературы}

1. Полевой В.В. Фитогормоны. Л., 1982. 248 с.

2. Чайлахян М.Х. Гормональная регуляция роста и развития высших растений // Успехи современной биологии. 1982. Т. 95, вып. 1. С. 70-75.

3. Кулаева О.Н., Воробьёва И.П. К вопросу о механизме действия кинетина на синтез белка // Физиология растений. 1962. Т. 9, вып. 1. С. 106-108.

4. Кулаева О.Н. Цитокинины, их структура и функции. М., 1973. 105 с.

5. Кулаева О.Н. Гормональная регуляция физиологических процессов у растений на уровне синтеза РНК и белка. М., 1982. 159 с.

6. Кулаева О.Н. Физиология растений. М., 1995. 661 с.

7. Чуб В.А. Рост и развитие растений. 2003. [Электронный ресурс]. URL: http: herba.msu.ru/russian.

8. Кравец В.С., Колесников Я.С., Кузнецов В.В., Романов Г.А. Регуляторы роста растений: внутриклеточная гормональная регуляция и применение в аграрном производстве // Физиология растений. 2008. Т. 55. С. 629-640.

9. Базарнова Н.Г., Катраков И.Б., Маркин В.И., Верещагина Т.В., Жилина И.Н., Уткова Е.А., Борисова Г.И., Семенков А.А. Росторегулирующие полимерные композиции на основе химически модифицированного растительного сырья для выращивания овощных культур, производимых тепличными технологиями // Вестник Алтайской науки. 2013. №1. С. 39-42.

10. Патент 2130947 (РФ). Способ карбоксиметилированиялигноуглеводных материалов / Галочкин А.И., Маркин В.И., Базарнова Н.Г., Заставенко Н.В., Крестьянникова Н.С.

11. Eyler R.W., Klug E.D., Diephuis F. Determination of degree of substitution of sodium carboxymethylcellulose // Analytical Chemistry. 1947. Vol. 19, N1. Pp. 24-27.

12. Маркин В.И. Карбоксиметилирование растительного сырья. Теория и практика. Барнаул, 2010. 167 с.

13. Бутенко Р.Г. Состояние и перспективы изучения морфогенеза растений // Всесоюзное общество физиологов растений. 1990. Вып. 8. С. 5-8.

14. Murashige T., Skoog F. A Revised Medium for Rapid Growth and Bioassaya with Tobacco Tissue cultures // Physiol. Plant, 1962. Vol. 15, N4. Pp. 473.

15. Доспехов Б.Д. Методика полевого опыта. М., 1979. 416 с.

16. Зайцев Г.Н. Математика в экспериментальной ботанике. М., 1990. 296 с.

17. Пищева Г.Н., Тихомирова Л.И. Изучение влияние 6-БАП в средах размножения на показатели этапа укоренения у ириса // Плодоводство и ягодоводство России. 2012. Т. XXXI, №2. С. 134-139.

Поступило в редакиию 2 февраля 2013 г.

После переработки 30 сентября 2013 г.

Bazarnova N.G., Tikhomirova L.I.", Frolova N.S., Pavlushin A.E., Kurchanova E.A. INFLUENCE AUXESIS PHYTOGENESIS MORPHOGENESIS IRIS SIBIRICA L., HEDYSARUM TEINUM KRASNOB. AND SYRINGA VULGARIS L. IN CULTURE IN VITRO

Altai State University, pr. Lenina, 61, Barnaul, 656049 (Russia), e-mail: L-tichomirova@yandex.ru

It was studied a growth-promoting activity of products of plant materials carboxymethylation as additives in the culture media used for micropropagation of plants Iris sibirica, Syringa vulgaris, Hedysarum teinum. The stimulating effect on gemmagenesis and rhizogenesis at Iris sibirica, Hedysarum teinum due to the high content of carboxymethylated lignin in the carboxymethylated plant materials. It was shown that the physiological effect of a stimulant relates to auxin type. It was noted a positive effect of adding carboxymethyl plant material in a culture medium for a number of plants in their collection in vitro.

Keywords: stimulator of growth, morphogenesis, in vitro, gemmogenez, rhizogenesis, auxins, Iris sibirica, Syringa vulgaris, Hedysarum teinum.

\footnotetext{
* Corresponding author.
} 


\section{References}

1. Polevoi V.V. Fitogormony. [Phytohormones]. Leningrad, 1982, 248 p. (in Russ.).

2. Chailakhian M.Kh. Uspekhi sovremennoi biologii. 1982, vol. 95, no. 1, pp. 70-75. (in Russ.).

3. Kulaeva O.N., Vorob'eva I.P. Fiziologiia rastenii, 1962, vol. 9, no. 1, pp. 106-108. (in Russ.).

4. Kulaeva O.N. Tsitokininy, ikh struktura i funktsii. [Cytokinins, their structure and function]. Moscow, 1973, 105 p. (in Russ.).

5. Kulaeva O.N. Gormonal'naia reguliatsiia fiziologicheskikh protsessov u rastenii na urovne sinteza RNK $i$ belka. [Hormonal regulation of physiological processes in plants at a level of RNA and protein synthesis]. Moscow, 1982, 159 p. (in Russ.).

6. Kulaeva O.N. Fiziologiia rastenii. [Vegetable physiology]. Moscow, 1995, 661 p. (in Russ.).

7. Chub V.A. Rost i razvitie rastenii. [Plant growth and development.]. 2003. URL: http: herba.msu.ru/russian. (in Russ.).

8. Kravets V.S., Kolesnikov Ia.S., Kuznetsov V.V., Romanov G.A. Fiziologiia rastenii, 2008, vol. 55, pp. 629-640. (in Russ.).

9. Bazarnova N.G., Katrakov I.B., Markin V.I., Vereshchagina T.V., Zhilina I.N., Utkova E.A., Borisova G.I., Semenkov A.A. Vestnik Altaiskoi nauki, 2013, no. 1, pp. 39-42. (in Russ.).

10. Patent 2130947 (RU). 1999. (in Russ.).

11. Eyler R.W., Klug E.D., Diephuis F. Analytical Chemistry, 1947, vol. 19, no. 1, pp. 24-27.

12. Markin V.I. Karboksimetilirovanie rastitel'nogo syr'ia. Teoriia i praktika. [Carboxymethylation of plant materials. Theory and practice.]. Barnaul, 2010, 167 p. (in Russ.).

13. Butenko R.G. Vsesoiuznoe obshchestvo fiziologov rastenii, 1990, no. 8, pp. 5-8. (in Russ.).

14. Murashige T., Skoog F. Physiol. Plant, 1962, vol. 15, no. 4, pp. 473.

15. Dospekhov B.D. Metodika polevogo opyta. [Technique of field experience]. Moscow, 1979, 416 p. (in Russ.).

16. Zaitsev G.N. Matematika v eksperimental'noi botanike. [Mathematics in Experimental Botany]. Moscow, 1990, 296 p. (in Russ.).

17. Pishcheva G.N., Tikhomirova L.I. Plodovodstvo i iagodovodstvo Rossii, 2012, vol. XXXI, no. 2, pp. 134-139. (in Russ.). 